\title{
Influence of Singing English Songs on Vocabulary Learning by Senior School Students in Guangzhou
}

\author{
Shuqiong Luo
}

\begin{abstract}
Considering the values of English songs as well as the fact that only a few studies applied English songs to help students learn English words but none of them investigated the effect of singing English songs to learn English vocabulary in secondary schools, this study, presents to exploring how singing English songs would influence senior secondary schools students' learning effectiveness and interest in English vocabulary in Guangzhou, a developed city in mainland China. The data were collected from fifty participants in Guangzhou. The qualitative methods consisted of four interviews and there were four experiments with two scenarios utilized respectively. Paired Sample T Test in SPSS was applied to analyze the data from the pre-tests and post-tests. The results demonstrated that singing English songs can be beneficial to senior high school students' learning effectiveness and interest in learning English vocabulary. As for the implications: singing English songs can be one of the scenarios to be introduced in practical English teaching and a well-equipped English teacher with musical abilities or knowledge is needed.
\end{abstract}

Index Terms-Singing English songs, English vocabulary, learning effectiveness, learning interest.

\section{INTRODUCTION}

With the trend of globalization, cultivating comprehensive and practical English learners has been an inescapable trend. English songs, as one of the natural but special language learning materials, can exert important parts in English acquisition, such as creating a pleasant learning atmosphere to motivate language learners in learning English [1]. Additionally, the National English Curriculum Standards for Common Senior High School [2] in China requires English teachers pay more attention to students' learning interest and students' flexibility to use English word. However, it is a common phenomenon that students find it hard to learn new English words especially to memorize them while exams in senior high schools often demand large vocabulary. As a result, some students feel under stress or would lose interest in learning English gradually.

If the process of learning English can be connected with singing English songs, with the help of the functions of music, it may help students while fit in the educational trend. Therefore, this research will shed lights on the effectiveness

Manuscript received June 5, 2019; revised July 30, 2019. This work was supported by Conghua Middle School, Guangzhou, China.

Shuqiong Luo is with Shantou University, Shantou, 510631, China (e-mail: sqluo@stu.edu.cn). and interest of using English songs in learning English vocabulary.

\section{LITERATURE REVIEW}

In a comprehensive review about the application of songs in English teaching field, using English songs to teach English can make motivate students owing to the appealing of songs [3]-[5], involve students into English class since that their own experience may be reflected or some views or attitudes in English songs may have significant impacts on their lives [3], improve learners' listening comprehension [6], help students learn grammar and facilitate L2 English learners' reading process [7]. Though using songs can display plenty of merits in English teaching, it doesn't mean that it is riskless or definitely outstanding when compared with other teaching methods. Not every song is appropriate for English teaching and the kinds of songs that are simple with emotional and dialogue features may let the learning process become easier.

In mainland China, English teachers tend to teach English words by explaining words in explicit ways [8]: in oral drills, introducing a word in context, reading words aloud and requiring students to recite the words [9]. However, due to the large size of class and the number of vocabulary that is needed to be taught during the limited courses, the presentation including the use of media or pictures given to students in Chinese English class about learning English words is usually too short and direct [8].

From the above studies, using English songs is an effective tool to benefit students in learning English though only some songs are suitable for English teaching or can exert significant effectiveness. For instance, songs that contain the lyrics with violence or sex may mislead students. Additionally, though the above researchers have realized the importance of English songs, few of them have carried out studies about sing English songs among students, especially about utilizing the singing of English songs to teach English words in mainland China [8]. Thus, the present study aims to find out whether singing English Songs can be used as a method to teach vocabulary in senior high schools. More importantly, the focus of this paper is singing English songs, which is different from the application of songs since singing is a more specific way. The research questions are:

1) Can singing English songs facilitate senior high school students in leaning meanings and spelling of English words?

2) Can singing English songs cultivate senior high school students' learning interest in learning English vocabulary? 


\section{RESEARCH METHODOLOGY}

\section{A. Participants and Experimental Design}

Fifty participants in Class Seven, Grade One in Conghua High School in Guangzhou were chosen for this research and four experiments were carried out. This school was a B-level school in Guangzhou, which meant that students' English proficiency was in the middle level among senior students in Guangzhou. Moreover, the chosen class ranked $8^{\text {th }}$ in the sixteen classes when considering the average scores of English tests. Among the participants, twenty four of them were males and the rest twenty six were females. In these four experiments, two kinds of teaching methods: Scenario A and $\mathrm{B}$ were applied to two experiments respectively and all the participants attended both scenarios: A and B, which implied that they attended all the four experiments. Here are the explanations of the processes of Scenario A and Scenario B in detail.

\section{B. Scenario A and Scenario B}

The only difference between Scenario A and B was that students were led to sing the chosen songs in Scenario A while reading the lyrics in the songs in Scenario B. Both Scenario A and B had two lessons taught by the same teacher with one week interval between each forty-minute-lesson. At the end of the lessons in both Scenario A and B, students were given post-tests to test their understanding of the chosen words and evaluated their interest towards the lessons. The procedures of Scenario A and B are illustrated in Table I.

TABLE I: PROCEDURES OF SCENARIO A \& B

\begin{tabular}{|c|c|c|}
\hline Process & $\begin{array}{l}\text { Scenario } \\
\text { A } \quad \text { (teaching }\end{array}$ & 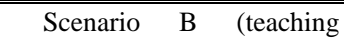 \\
\hline $\begin{array}{c}(40 \\
\text { minutes) }\end{array}$ & $\begin{array}{l}\text { students to learn the } \\
\text { meanings, pronunciation } \\
\text { and spelling of the tested } \\
\text { words by singing English } \\
\text { songs) }\end{array}$ & $\begin{array}{l}\text { students to learn the } \\
\text { meanings, pronunciation and } \\
\text { spelling of the tested words } \\
\text { by reading ) }\end{array}$ \\
\hline $\begin{array}{l}\text { sing/read } \\
\text { ing of } \\
\text { songs } \\
(5 \\
\text { mins) }\end{array}$ & $\begin{array}{l}\text { Students watched the } \\
\text { MV of the song that they } \\
\text { were tested to know about } \\
\text { the background of the song. }\end{array}$ & $\begin{array}{l}\text { Students learned to know } \\
\text { the background and main } \\
\text { content of the song by the } \\
\text { introduction from the teacher. }\end{array}$ \\
\hline \multirow[t]{4}{*}{$\begin{array}{l}\text { learning } \\
\text { words } \\
(20 \\
\text { mins })\end{array}$} & $\begin{array}{l}\text { I. Students learned to } \\
\text { sing the song by one } \\
\text { sentence and one sentence } \\
\text { taught by the teacher at the } \\
\text { first time. ( } 3 \text { mins) }\end{array}$ & $\begin{array}{l}\text { I. Students learned to read } \\
\text { the song by one sentence and } \\
\text { one sentence taught by the } \\
\text { teacher at the first time. ( } 3 \\
\text { mins) }\end{array}$ \\
\hline & $\begin{array}{l}\text { II. After the first time } \\
\text { singing, students were told } \\
\text { the words that they were } \\
\text { tested later. ( } 1 \text { mins) }\end{array}$ & $\begin{array}{l}\text { II. After the first time } \\
\text { reading, students were told } \\
\text { the words that they were } \\
\text { tested later. ( } 1 \text { mins) }\end{array}$ \\
\hline & $\begin{array}{l}\text { III. Teacher led students } \\
\text { to sing the song. During } \\
\text { this process of singing, } \\
\text { firstly, teacher let students } \\
\text { guess the meaning of the } \\
\text { tested words after singing } \\
\text { the sentence with the tested } \\
\text { words. ( } 4 \text { mins) }\end{array}$ & $\begin{array}{l}\text { III. Teacher led students to } \\
\text { read the song. During this } \\
\text { process of reading, firstly, } \\
\text { teacher let students guess the } \\
\text { meaning of the tested words } \\
\text { after reading the sentence } \\
\text { with the tested words. (4 } \\
\text { mins) }\end{array}$ \\
\hline & $\begin{array}{l}\text { IIII. Some other } \\
\text { sentences that contented the } \\
\text { same meanings of the tested } \\
\text { words were given to the } \\
\text { students. And students } \\
\text { were asked to work in } \\
\text { groups of four to conclude } \\
\text { the meanings of the tested }\end{array}$ & $\begin{array}{l}\text { IIII. Some other sentences } \\
\text { that contented the same } \\
\text { meanings of the tested words } \\
\text { were given to the students. } \\
\text { And students were asked to } \\
\text { work in groups of four to } \\
\text { conclude the meanings of the } \\
\text { tested words. ( } 4 \text { mins) }\end{array}$ \\
\hline
\end{tabular}

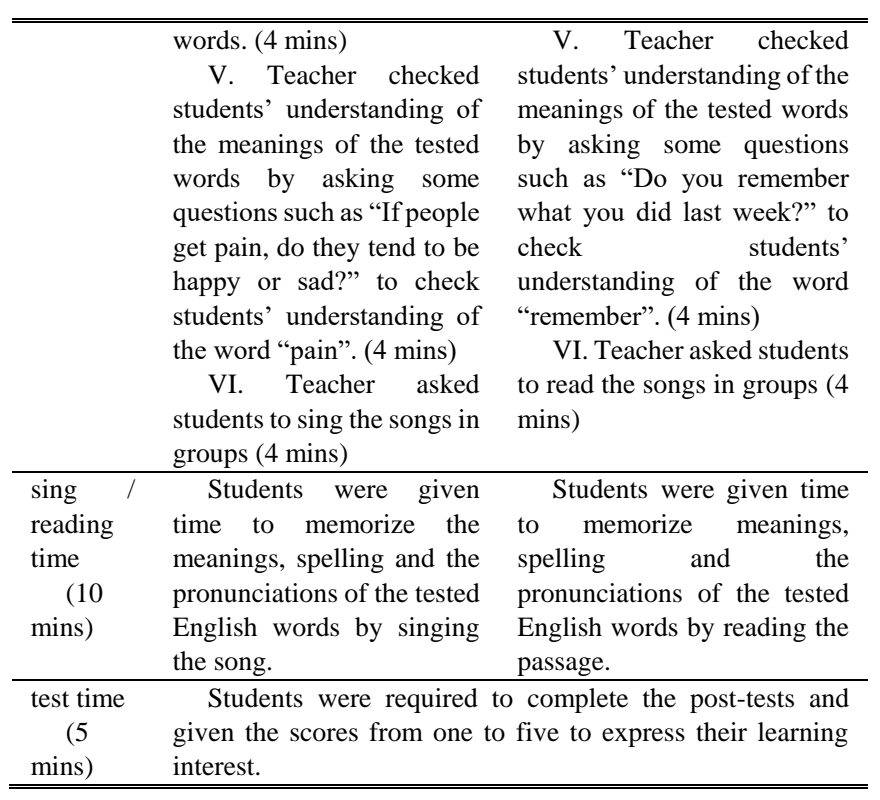

\section{The Selection of the Songs}

I did a survey before the experiments were started among students in senior one in Guangzhou to know students' general interest towards English songs, for example their preferred styles and singers. After analyzing their preference and considering the number of male participants and females, the songs chose were two from female singers (Because of You by By 2 \& Rise by Katy Perry) and two from male singers (Pray by Justin Bieber \& See You Again by Charlie Puth) to reduce the possibility that students were not willing to sing the songs sung by the singers from opposite gender.

In this research, the songs selected conformed to the grammatical rules, with positive topics, lyrics that explained the content clearly and within or near the range of the first octave with obvious rhythms [10].

\section{The Selection of the Tested Words and The Design of the Tests}

The tested words were the ones that students would learn in senior two, which were a bit difficult but within students' range to reach and were suitable for students' psychological level. There were seven words in each pre-test and post-test finally. Due to the theory that human's short-term memory can hold $7( \pm 2)$ elements [11], pre-tests before the experiments consisted of nine words from every teaching material, aimed at defining whether the words were difficult for students and how many words could be tested. After analyzing students' performance in pre-tests, eight words were eliminated from the tests since that some students had mastered one or two words selected for each experiment.

The post-tests were aiming at testing students' understanding of the tested words and test students' interest towards the lessons. There was no question given to students about their interest. The number "one" in this experiment meant dislike at all and the number "five" meant likes very much. In these tests, there were three types of questions:

1) Use words to make up meaningful sentences (e.g. use the word "appetite" to make up a sentence);

2) Write down the Chinese meanings of the given English words (e.g. "vide___");

3) Write down the English words of the given Chinese. 


\section{E. Teaching of the Tested Words}

In the experiments, the tested words were taught from three aspects: English meanings and spelling and pronunciation. Participants were given almost three sentences of each word for concluding and understanding the meanings of the tested words. Nearly all the sentences were selected from the Oxford English Dictionary, which could provide participants with authentic contexts. For instance, about the word "appetite", there were three sentences for students. They were:

1) The smell from the garbage dulled her appetite. (Oxford English Dictionary)

2) Exercise will improve your appetite for food. (Oxford English Dictionary)

3) The walk gave me a good appetite. (Oxford English Dictionary)

In terms of teaching the spellings of the tested words, teachers told the students some points when referring to the words. Questions were asked to check students' understanding about the meanings of the tested words in the procedures of Scenario A and B. Here are some examples of the questions:

1) "If I say I lost my appetite, it means I would like to eat more or eat less?" was used to check whether the participants understood the meaning of the word "appetite".

2) "Is a sinner a person that is beneficial to the society?" was applied to check students' understanding of the meaning of the word "sinner".

\section{F. The Marking Criteria}

Each participant had two tests scores and one score for interest evaluation for each experiment. The maximum mark of each test was seven and the minimum one was zero. There were some criteria to evaluate answers to different types of questions in the tests and the full mark of each question was one point.

As for the questions "making up sentences by using tested words", students' grammatical mistakes were ignored. Whether they could get the marks only depends on whether the sentence they made could express the meanings of the tested words even though with some grammatical mistakes or inappropriate expressions. Students could get a full mark (seven) in each test.

For example, when student wrote down a sentence:

"I lose my appetite after fail in the math exam recently." or "I don't has the appetite to eat the fruits."

he got a one point in this question although there were wrong tense and spelling in this sentence.

But if the sentence was written as:

"I like appetite." or "Appetite is not attractive."

these sentences could not get any point because obviously, the writer of this sentences did not understand the meaning of the word "appetite".

When referring to the questions "write down the English words when given Chinese or write the Chinese words when given English ones", one point was given to each answer if students' answers could explain the same meanings with the correct answers and the spelling of the English words were considered. If students gave other words rather than the tested words, marks were given. If students did not have the correct spelling of the tested words, they could not get the marks. For instance, when student spelt the word "palm" as "plam", he got no mark in that question.

Actually, there was another English teacher in this school helped me do the second marking of the post-tests and pre-tests three days after each experiment. The results of the two markers were compared and there were a few discrepancies between the results after analyzing the significance between them. Thus, the results put into analysis were the average scores between the two markers.

\section{DATA ANALYSIS AND INTERVIEWS}

In this research, Paired-Sample $\mathrm{T}$ Test in 21th version SPSS was used to deal with the collected data. The data were students' scores from pre-tests, post-tests and scores about students' learning interest with fifty samples. Each sample had one variable: teaching methods while the scores of the pre-tests and post-tests were separated according to different tests when analyzing.

The qualitative method in this research contained four interviews with the same four questions and two female participants and two males were selected randomly as interviewees. Participants' understanding about the interest and preferences towards two scenarios and their thoughts about learning effectiveness under two scenarios were the objectives of the interviews. Students were asked to speak English in the interviews but when they had problem expressing their ideas clearly in English, they can speak Chinese.

Since that I was the teacher in the four experiments, in order not to involve some factors that might influence the interviewees' true ideas, the interviewer was another teacher, who just asked the questions I designed in English and recorded what the participants have said and gave no feedback to the interviewees. The interviews were transcribed and translated later by myself. The questions in the interviews were:

1) Do you think the songs are difficult when learn to sing or read?

2) After having four classes about learning vocabulary, which kind of class do you prefer when considering your learning interest and why?

3) After having four classes about learning vocabulary, which kind of class do you prefer and why, after considering you learning effectiveness?

4) What suggestions would you give to these four classes?

\section{RESULTS}

\section{A. Scores Difference on Learning Effectiveness by Teaching Methods}

The data from Table II all were collected from post-tests in the four experiments. According to Table II, due to the means and the standard deviations, it can be speculated that Scenario A is more effective in affect students' learning effectiveness in learning English vocabulary than Scenario B but the interior difference among the performance of the students' is 
larger in Scenario A than in Scenario B.

(In all the tables in this paper, "S1" refers to the first experiment of Scenario A, "S2" means the second experiment of Scenario A, "R1" refers to the first experiment of Scenario B and "R2" means the second experiment of Scenario B.)

TABLE II: SCORES OF LEARNING EFFECTIVENESS BY TWO TEACHING METHODS (PAIRED SAMPLES STATISTICS)

\begin{tabular}{|c|c|c|c|c|c|}
\hline & & Mean & $\mathrm{N}$ & Std. Deviation & $\begin{array}{l}\text { Std. } \\
\text { Error } \\
\text { ean }\end{array}$ \\
\hline \multirow{2}{*}{ Pair 1} & $\begin{array}{c}\text { S1 } \\
\text { (post-test) }\end{array}$ & 6.54 & 50 & .706 & .100 \\
\hline & $\begin{array}{c}\mathrm{S} 2 \\
\text { (post-test) }\end{array}$ & 6.40 & 50 & .756 & .107 \\
\hline \multirow{2}{*}{ Pair 2} & $\begin{array}{c}\mathrm{S} 1 \\
\text { (post-test) } \\
\end{array}$ & 6.54 & 50 & .706 & .100 \\
\hline & $\begin{array}{c}\mathrm{R} 1 \\
\text { (post-test) }\end{array}$ & 6.38 & 50 & 1.008 & .143 \\
\hline \multirow{2}{*}{ Pair 3} & $\begin{array}{c}\mathrm{S} 2 \\
\text { (post-test) }\end{array}$ & 6.40 & 50 & .756 & .107 \\
\hline & $\begin{array}{c}\mathrm{R} 1 \\
\text { (post-test) }\end{array}$ & 6.38 & 50 & 1.008 & .143 \\
\hline \multirow{2}{*}{ Pair 4} & $\begin{array}{c}\mathrm{S} 2 \\
\text { (post-test) } \\
\end{array}$ & 6.40 & 50 & .756 & .107 \\
\hline & $\begin{array}{c}\mathrm{R} 2 \\
\text { (post-test) }\end{array}$ & 5.92 & 50 & .900 & .127 \\
\hline \multirow{2}{*}{ Pair 5} & $\begin{array}{c}\mathrm{R} 1 \\
\text { (post-test) }\end{array}$ & 6.38 & 50 & 1.008 & .143 \\
\hline & $\begin{array}{c}\mathrm{R} 2 \\
\text { (post-test) }\end{array}$ & 5.92 & 50 & .900 & .127 \\
\hline \multirow{2}{*}{ Pair 6} & $\begin{array}{c}\mathrm{S} 1 \\
\text { (post-test) } \\
\end{array}$ & 6.54 & 50 & .706 & .100 \\
\hline & $\begin{array}{c}\mathrm{R} 2 \\
\text { (post-test) }\end{array}$ & 5.92 & 50 & .900 & .127 \\
\hline
\end{tabular}

TABLE III: SCORES OF LEARNING EFFECTIVENESS BY TWO TEACHING METHODS (PAIRED SAMPLES STATISTICS)

\begin{tabular}{|c|c|c|c|c|c|}
\hline & \multicolumn{4}{|c|}{ Paired Differences } & \multirow{3}{*}{$e^{t}$} \\
\hline & \multirow[t]{2}{*}{$\begin{array}{r}\text { Mean Std. } \\
\text { Devia }\end{array}$} & \multicolumn{3}{|c|}{$\begin{array}{l}\text { Std. } 95 \% \text { Confidence } \\
\text { Error Interval of the } \\
\text { MeanDifference }\end{array}$} & \\
\hline & & & Lower & Upper & \\
\hline $\begin{array}{l}\text { Pair } 1 \\
\text { S1 (pre-test) } \\
\text {-S1 } \\
\text { (post-test) }\end{array}$ & -6.469 .710 & .101 & -6.673 & -6.265 & -63.77350 .000 \\
\hline $\begin{array}{l}\text { Pair } 2 \\
\text { S2 (pre-test) } \\
-\mathrm{S} 2 \\
\text { (post-test) }\end{array}$ & -6.367 .755 & .108 & -6.584 & -6.150 & -59.00650 .000 \\
\hline & -6.388 .953 & .136 & -6.662 & -6.114 & -46.89950 .000 \\
\hline
\end{tabular}

Pair 3

R1 (pre-test)

$-\mathrm{R} 1$

(post-test)

\begin{tabular}{llllll}
\hline Pair 4 & -5.939 .876 & .125 & -6.190 & -5.687 & -47.46750 .000 \\
R2 (pre-test) & & & & \\
-R2 & & & & \\
(post-test) & & & &
\end{tabular}

As for Table III, from the comparison between pre-tests and post-tests using Pair Sample T Test, the means in pre-tests in the four experiments are nearly the same, which represents that difficulties of the words tested for students are at the same level. After four experiments' learning, through the changes of the means between the pre-tests and the post-tests, it can be apparently concluded that students have made an overall improvement in the four post-tests in two scenarios and students' improvements under Scenario A is larger than that in Scenario B.

To be more scientifically, the data of significance is statistically significant. The obvious significance illustrates that the improvement of students' performance in post-tests is significant and each lesson has positive effect on students' learning effectiveness in learning English vocabulary while the lessons that contained singing songs are more useful than the lessons utilized Scenario B.

When considering students' performance in these lessons, students were more focused when singing English songs than reading. Referring to the results in post-tests, even the three naughty male students who were always absent-minded in the lessons under the guidance of Scenario B and got low marks in the post-tests after the experiment contained Scenario B, took active part in singing English songs and got nearly full marks in the post-tests after Scenario A was carried out. Thus, Scenario A is much more useful than Scenario B when considering the learning effectiveness.

\section{B. Scores Difference on Learning Interest by Teaching Methods}

As seen in Table IV, concluded from the means and the significance, Students have higher learning interest under Scenario A than under Scenario B. Therefore, Scenario A is a better way to cultivate students learning interest towards English words than Scenario B.

TABLE IV: SCORES OF LEARNING INTEREST By TwO TEACHING METHODS (PAIRED SAMPLES STATISTICS)

$$
\begin{aligned}
& \text { Pair } 1 \text { Scenario A (post-test) } \\
& \text { Scenario B (post-test) }
\end{aligned}
$$

\begin{tabular}{|c|c|}
\hline Mean & -.580 \\
\hline Std. & 1.513 \\
\hline Std. Error Mean & .214 \\
\hline $\begin{array}{l}\text { 95\% Confidence Interval of the } \\
\text { Difference } \\
\text { (lower) }\end{array}$ & .150 \\
\hline $\begin{array}{l}\text { 95\% Confidence Interval of the } \\
\text { Difference } \\
\text { (upper) }\end{array}$ & 1.010 \\
\hline $\mathrm{t}$ & 2.711 \\
\hline $\mathrm{df}$ & 50 \\
\hline Sig (2-tailed) & .009 \\
\hline
\end{tabular}

\section{Results from the Interviews}

$75 \%$ of the participants thought the teaching materials (songs) were not difficult owing to the help from the guidance of the teacher and the MV. When referring to the learning interest, $75 \%$ of the interviewees preferred Scenario A since that Scenario A improved their motivation from the free atmosphere, organized class, interesting feelings, personal development and the teacher's charming. However, 
the results of the interviews shows that singing songs was not an easy way to every student and students may chose Scenario B because they had always received that kind of teaching method and had got used to it. When considering the learning effectiveness, the interviewees who supported Scenario A thought that singing songs was less difficult to be reviewed all the time.

\section{DISCUSSIONS}

\section{A. Learning Effectiveness of the Two Scenarios}

As a teacher who has teaching experience in two senior high schools, I have found that most students suffered from heavy pressure in learning English vocabulary and in the meantime, most English lessons just pushed students to learn whereas paid less attention to their learning interest. Students needed something to motivate their learning interest and singing English songs can serve as an approach to satisfy their needs. However, given that most students have acquired traditional ways to learn words such as reading and reciting since their primary schools, they may have got accustomed to Scenario B when considering their learning effectiveness.

\section{B. Learning Interest of the Two Scenarios}

The percentages of students who gave number 1, 2, 3, 4, 5 respectively to Scenario A are 2\%, 4\%, 20\%, 36\% and 38\% while to Scenario B are 2\%, 6\%, 46\%, 36\% and 10\%. From the percentages, Scenario A is more effective in cultivating students' learning motivation towards English words than Scenario B.

\section{EDITORIAL POLICY}

The submitting author is responsible for obtaining agreement of all coauthors and any consent required from sponsors before submitting a paper. It is the obligation of the authors to cite relevant prior work.

Authors of rejected papers may revise and resubmit them to the journal again.

\section{CONCLUSION}

In this paper, we have demonstrated that 1) singing English songs is more effective in improving students' learning effectiveness and learning interest towards English vocabulary than the reading method and 2) singing English songs to learn English words can become a scenario for English teachers to utilize in practical English lessons.

However, to achieve success in Scenario A into actual practice, it needs an English teacher who can teach singing and know how to explain musical knowledge understandably to student as well as selecting suitable teaching materials.

Here are some implications from this study. It is possible that some variances result from other factors though with control. Therefore, more cautions should be taken in the determination of the impact of one single factor in teaching or assessment in second language acquisitions. Moreover, the selection of songs needs teachers' time and knowledge both in English and music because many English popular songs are not appropriate for learning. During this research, I did the songs selection myself, which took me two weeks to establish a song-collection with 58 English songs, analyze the songs one by one and finally chose four of them as teaching materials. As far as I am concerned, in practical teaching, joint efforts between English teachers and help from music teachers are needed in choosing songs. Additionally, I have found that students were more motivated when a song they learned was sung by the singer they liked or a song came from a famous movie they were familiar with in the experiments. Thus, before selecting songs for teaching, doing a survey among students to know more about their favorite singers or songs seems helpful.

Besides, some students were not confident enough to sing the songs maybe due to the fact that the songs were not easy to sing well or they were afraid of being laughed at by other classmate. In practical teaching, if teachers come across this situation, they can sing with students to reduce students' pressure and give encouragement to the whole class, trying to avoid inviting certain student to sing alone, which may increase students' stress.

This work, to some extent, fills the gap among the existing studies. However, it has several limitations. First, samples in the experiments were in a homogeneous group with small size. Second, the research lacked authoritative method to test whether the four songs chosen in the experiments have the same difficulty in both English and music acquisitions. Third, the tests designed by my own to test students' learning effectiveness though based on some theories, may have some limitations.

\section{CONFLICT OF INTEREST}

The authors declare no conflict of interest.

\section{AUTHOR CONTRIBUTIONS}

Shuqiong LUO finished the whole paper, including conducting the research, analyzing the data and writing the paper. Shuqiong LUO had approved the final version.

\section{ACKNOWLEDGMENT}

Shuqiong LUO thanks all the participants in CongHua High School and Dr. Alice Chan, from City University of Hong Kong for her helpful guidance.

\section{REFERENCES}

[1] C. Salcedo, "The effects of songs in the foreign language classroom on text recall, delayed text recall and involuntary mental rehearsal," Journal of College Teaching and Learning, vol. 7, no. 6, pp. 19-30, 2010 .

[2] National English Curriculum Standards for Common Senior High School, Chinese National Department of Education, 2017, pp. 1-33.

[3] C. Cheung, "The use of popular culture as a stimulus to motivate secondary students' English learning in Hong Kong," ELT Journal, vol. 55, no. 1, 2001.

[4] M. Chou, "Assessing English vocabulary and enhancing young English as a foreign language (EFL) learners' motivation through games, songs, and stories," Education, vol. 42, no. 3, pp. 284-297, 2014.

[5] S. Jarvis, "How effective is it to teach a foreign language in foundation stage through songs and rhymes?" Education, vol. 41, no. 1, pp. 47-54, 2013

[6] R. Mahin and A. Touran, "The effect of listening to English songs on Iranina EFL pre-intermediate learners' listening comprehension," The Journal of Applied Linguistics, vol. 8, no. 16, pp. 29-44, 2015. 
[7] B, Iwasak, T. Rasinski, K. Yildirim, and B. S. Zimmerman, "Let's bring back the magic of songs for teaching reading," Reading Teacher, vol. 6, pp. 137-141, 2013.

[8] E. Tang, \& N. Hilary, "Teaching vocabulary in two Chinese classrooms Schoolchildren's exposure to English words in Hong Kong and Guangzhou," Language Teaching Research, vol.7, no. 1, pp. 65-77, 2003.

[9] J. Chen, "Probe into the blind zones of Chinese EFL students' vocabulary learning," Theory and Practice in Language Studies, vol. 3, no. 7, pp. 1214-1220, 2013.

[10] S. E. Pitts, "Music, language and learning: Investigating the impact of a music workshop project in four English early years settings," International Journal of Education \& the Arts, vol. 17, no. 20, pp. 1-26, 2016.

[11] G. A. Miller, "The magical number seven, plus or minus two: Some limits on our capacity for processing information," Psychological Review, vol. 63, pp. 81-97, 195.
Copyright ( $\odot 2019$ by the authors. This is an open access article distributed under the Creative Commons Attribution License which permits unrestricted use, distribution, and reproduction in any medium, provided the original work is properly cited (CC BY 4.0).

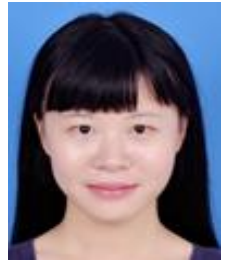

Shuqiong Luo was born in 1995 in China. She got her MA degree in English studies (TESL) in the Department of English of City University of Hong Kong in Hong Kong in 2018 and her BA degree in English language and literature (education) in the Department of English of South China Normal University in Guangzhou, China in 2017. She is a current instructor in Shantou University in China. Her research interests include the application of music to language class and e-learning. 